\title{
School Council Policy in Punjab: Policy Formulation without Participation of Stakeholders
}

\author{
Rafaqat Islam *
}

\begin{abstract}
Quality and equitable access to education largely remain mere aspirations for the populace. Despite the earnest efforts and commitment on the part of Government of the Punjab as well as support of international educational organizations, the goals continue to elude all efforts. This research has been conducted with the assumption that involvement of community in the major stages of policy-making in Pakistan is minimal. The study has highlighted the lack of effective community participation both at policy formulation and implementation stages in the Punjab Province. It has attempted to point out the irritants that discourage community participation. The researcher seeks a solution to the problem by suggesting devolution of planning to lower levels to incorporate local interests and working upwards to the higher tiers in a democratic way. Such an approach will beget ownership and maintain interest of the stakeholders. Such a process would encompass the advantage of bureaucratic expertise while promoting the interest and capabilities of populace.

Keywords: School-based management, school management committee, village education committee, education sector reform program, social action program.
\end{abstract}

\section{Introduction}

Over the past decade or so, the government of the Punjab has managed to provide reasonable educational facilities throughout the province. Although this measure has made elementary education more accessible, the poor quality of education remains a major problem. Besides, the lack of practical benefit and, in several cases, high opportunity cost cause disillusion to parents and students. A general evaluation of the situation along with a comparative analysis of educational effort in various developed and developing countries reveals that mere increased budgetary allocations without institutional reforms, particularly at the conception level, cannot significantly increase the qualitative output of the school education sector and the enthusiasm of masses for education. In its attempt to address the problem, the government of the Punjab has been trying to devise various policies for the participation of local community in the school education processes. However, such policies have not been carefully thought through, for example composition of school councils (school management committees) had to be changed several times. Moreover, policy formulation tends to be bureaucratic and lacks coordination among the stakeholders. Also, there exists a tendency to generalize policy implementation procedures disregarding the limitations of particular communities.

\footnotetext{
${ }^{*}$ PhD Scholar, National Defence University, Islamabad. Email: rafaqatislam@yahoo.com
} 
The solution to the problem lies in enhancing community participation in both educational planning and implementation. Coming from an educationist family and interacting with parents/relatives of students, members of educational bureaucracy from clerk to Directors of Public Instruction( serving and retired) and review of literature in connection with present research on School Councils, it seems that there is a need for the harmonization of bureaucratic and community efforts. Such harmonization is likely to increase resources and enhance accountability in educational process leading to greater retention rates, easier access to education and better quality of education.

\section{Concept of School-Based Management}

Realizing the need for participation of community, the governments around the world have embarked upon decentralizing educational systems in the hope of improving quality and increasing quantity of education in their respective countries. Such decentralization of decision making power to the school level is popularly known as school-based management (SBM). Usually it took the form of School Management Committees (SMCs), School Councils or Village Education Committees (VECs). Practice of SMCs started in the USA during 1960s and quickly spread to Australia, Canada, New Zealand, Latin America, and several countries in Africa and Asia.

School-based management reforms are challenging the conventional education governance structures in order to increase school autonomy. These reforms aim at strengthening incentives for schools to deliver services that are responsive to the needs of the communities they serve. Advocates of SBM argue that the devolution of decision making authority to schools can facilitate and enhance community participation (De Grauwe, 2005). Such devolution that strengthens the parental voice and listens to the school management while giving them greater incentives will lead to enhanced efficiency in provision of services. The education system is likely to be more responsive as decision making shifts from the bureaucratic policy makers towards the school management and the community they serve.

Shaeffer (1992) believes that most educational decentralization projects have certain spelled-out objectives and the most common objectives of various decentralization projects in both developed and developing countries are:

(a) To generate more resources.

(b) To ensure equitable resource allocation.

(c) To ascertain effective use of resources.

(d) To enhance decision-making standards by relating to local conditions, needs and indigenous culture.

(e) To encourage innovation and participation

(f) To increase local responsibility and accountability.

(g) To stimulate communication down and (especially) up the system of control. 
Thus, educational decentralization ensures wider representation of legitimate interests in education (Weiler, 1990) and makes the community responsible for educational quality. To Shaeffer (1992), such community participation means inclusion of the community in:
(a) Decision making
(b) Problem identification
(c) Feasibility study
(d) Planning and plan implementation
(e) Evaluation

If such participation takes place, it brings following benefits to the system and the community:

(a) People gain knowledge and awareness of their own social, economic, and political conditions.

(b) They make and act on choices and construct their own futures through a process of analysis and action.

(c) They gain control and power over resources, goals, processes of development and reform.

Community participation in education can take two forms - informal and formal. The informal system has been in practice since long, as the local communities contribute to educational effort by providing land, material and manual help in construction and even cash contributions. However, it was felt that rather than confining the communities' participation to the donation of land and construction of a building for the school, it would be worthwhile to involve them more actively in various activities of the school. Thus, the formal system in the form of School Management Committees (SMCs), School Councils or Village Education Committees has been put in place for community participation in the educational matters. Parent-Teacher Associations are also a form of this formal system. These are mostly constituted in urban and affluent societies for people's participation in school affairs.

\section{Decentralization of School Education in Pakistan}

Educationists in Pakistan have been aware of the importance of community participation in education, particularly at the primary level since long. The 1959 Commission on Education propounded in its report that more the villagers or other local communities are involved in and are responsible for the operation and upkeep of primary school, the more they would feel a sense of proprietorship of the school, and the more importance they would attach to education and the necessity for their children taking full benefit from it (Government of Pakistan, 1959). Further, the commission thought, it would be beyond 
the resources of government to find the money for all the costs involved in implementing compulsory education. The commission opined that a considerable part of the effort would have to be made by local communities (Ibid).

New Education Policy, 1972-80, also promised setting up of education councils at the national, provincial, district and institutional levels. Such councils were to assist in the formulation and evaluation of education policies and practices. The councils were to include elected representatives of National and Provincial Assemblies and Local Bodies, citizens of various shades of opinion from different walks of life interested in education and representatives of teachers, students and education department, etc. The councils were to harness and mobilize latest educational techniques and resources for various specific areas of activity (Government of Pakistan, 1972).

The 1992 Educational Policy emphasized that the programme of universal primary education was to be carried out through active participation of the community and elected representatives with village as a unit in rural areas and Mohallah in the urban areas (Government of Pakistan, 1992). According to National Educational Policy - 1998-2010, selected management functions in elementary education were to be decentralized towards the community at district and school levels, with local bodies assisting in the organization (Government of Pakistan, 1998). However, the rhetoric remained restricted to policy pronouncements and not many measures were taken to actually decentralize education. On the contrary, nationalization of private and autonomous bodies' institutions in 1970s resulted in the further centralization of the education system.

\section{The Punjab Province: Structure of School Education Policy and Plan- ning}

In Punjab, there are five tiers of administrative structure of school education: Provincial Secretariat, Provincial Directorates of Public Instruction, District Office, Tehsil Office and Markaz (a cluster below Tehsil level). The Provincial School Education Department is headed by the Secretary who is assisted by Additional Secretaries, Deputy Secretaries and Section Officers with supporting staff. At the provincial level, there are two Directorates of Public Instruction, one for elementary education and the other for secondary. Director Public Instruction (Elementary) is the executive head of the office for implementing plans and policies of the Government in the field of elementary education in the entire Province. There are Deputy Directors and Assistant Directors with supporting staff to help the Director Public Instruction (DPI).

The Director of Public Instruction (Elementary) has to carry out the plans and programmes of the Government in the field through District, Tehsil and Markaz Education Officers. In addition to the above tiers, a Programme Monitoring and Implementation Unit, headed by a director, also functions in the School Education Department. This unit is primarily responsible for coordination and monitoring of donors funded programmes, however, it has taken over the responsibility of policy design and revision. Theoretically, provincial authorities give direction and guidelines to the lower tiers of educational administration and in response, the field staff at cluster level namely the AEOs collects and consolidates information and gives input for policies and development plans. Such input 
is further analyzed and endorsed at district and provincial levels and transmitted to the PMIU, School Education Department. However, in the particular case of school council policy, conditions were imposed from donors and the provincial department carried out the same without much thought, or any input from the lower hierarchy.

\section{The Punjab Province: Decentralization of School Education}

It was in the early 1990s that Pakistan's school education system came under the influence of donors. Pakistan had to accept the idea of school-based management at the behest of donors in Social Action Program (SAP) launched in 1992/3 and thus a notification for the constitution of School Management Committees (SMCs) in primary and elementary schools was issued in 1994 (Government of the Punjab, 1994). This idea of SMCs did not properly emerge from any planning undertaken by the educational bureaucracy, which is elaborate enough.

The policy so adopted in the Punjab Province in 1994, has been amended several times during the last two decades through notifications or issuance of new/revised policy in the hope of clarifying ambiguities hitherto prevalent in the functioning of school committees/councils. However, several studies/validation reports regarding decentralized management of the elementary education indicate that all these policy measures have not succeeded in bringing about desired educational reforms.

Some of the reasons for failure mentioned in literature on the subject include elite capture of school councils (Khan, 2007), continuous ignorance of council rules among various stakeholders (Cambridge, 2014), complaints from members of community, of perceived inattention to their point of view by head-teachers and consequent lack of interest on the part of communities (Habib, 2010), and above all, no tangible improvement in educational outcomes among students still in sight (Channa, 2011). However, a cursory look at the contents of School Council policies/directives issued from time to time and incremental changes made in them, so that the real cause of policy failure lies with the policy designing process, particularly ill-coordination and non-participation of relevant stakeholders.

The idea behind the establishment of School Management Committees/School Councils was that desirable educational goals could be achieved through educational devolution/community participation and these setups would help involve the community in school affairs. But the mere issuance of a notification cannot bring community participation. Community participation has to be cultivated through community mobilization.

The concept of adding an element of community participation in school management first came to prominence in 1994 during the implementation of the Social Action Program (SAP), a large-scale public sector human development programme that was conceived and implemented through the decade of the 1990s. School Management Committees (SMCs) and School Repair Committees (SRCs) were constituted for all primary and elementary schools, and were given the mandate of motivating parents in their communities to enroll, and keep children in school: monitor teacher attendance; and participate in the management of financial and administrative affairs of the school amongst other things. SMCs, which were required to have 12 members, were also to prepare School Develop- 
ment Plans, to identify funding requirements for civil works and other school activities, as well as to identify possible funding sources. SRCs were primarily responsible for overseeing the execution of civil works in schools.

Although the notification for the establishment of School Management Committees was issued on the behest of donors, it opened a window of hope for community participation in the Province's elementary education. But policy could not yield dividends mainly due to two reasons: firstly, the composition of the SMCs required under the policy did not take into account particular needs and capacities of the stakeholders, secondly, input from parents/communities, teachers, head-teachers and district educational administrations was not incorporated in the policy-making process. Particularly, as the field research reveals, even the district educational administration was not consulted during formulation of the SMC policy. On the contrary, they were simply ordered for the constitution of the management committees at school level.

Public policy is a choice made in response to public issues or problems by the government, based on values and norms. It attempts to reconcile an issue or a situation with the general norms (Geurts, 2014). It is therefore important to identify political issues and public problems regarding education before formulating a policy to redress them. Any comprehensive policy making process would require the participation of stakeholders at all stages of policy making such as proposing initiatives, practicing advocacy, mobilizing stakeholders, holding consultations, building opinions and taking positions. However, in the case of School Management Committee's policy, in 1994, the Punjab Education Department, on the behest of provincial government simply issued notification to lower tiers ordering the formulation of School Management Committees and also School Repair Committees.

During field research and in-depth interviews, a retired Director Public Instruction (Elementary) revealed that the initial design for SMC policy was proposed by some consultant contracted by Punjab Education Department. This indicated neglect of the political dimension of policy making process which was essential for the formulation as well as implementation of any public policy. In this particular case stakeholders were Education Department, District Education Administrations, head-teachers, teachers, parents of the children and community at large and, of course, the provincial legislative assembly. No evidence regarding participation of these stakeholders beyond Programme Monitoring and Implementation Unit (PMIU) of School Education Department existed. The model based on the experiences of developed countries could not bear any fruit in the context of Punjab.

SMCs remained largely ineffective in the first four years of their existence, lacking as they did the capacity, authority and financial resources to effectively plan the school development. A problem of elite capture also became apparent as SMCs included community notables as members who may or may not have had children studying in the particular school. In 1998, the SMCs were reconstituted to include mainly parents and teachers, and the number of members was reduced from 12 to 9. In addition, each SMC was required to maintain a bank account and take responsibility for minor repairs and maintenance of school infrastructure. However, the institution remained ineffective, mainly because of the capacity constraints of SMC members who could not keep accounts, main- 
tain records of the meetings or manage small contracts.

Indeed, there cannot be a standard recipe for achieving community participation; what makes any policy 'work' varies tremendously across different economic, political, and cultural contexts. Nasira Habib’s study published in April 2010 (Habib, 2010) reports:

"In Pakistan, SMCs were started in 1994 but desirable results have not been achieved. Community voice was heard but not acted upon. In three out of five districts the respondents were not aware of the new structure of SC."

The report indicated that most of SMCs were still largely controlled by head-teachers who continued to select members and school management remained de facto with the staff. Most SMC members knew little if anything, about their roles and responsibilities. In SMCs where teachers were not from the same village, there was little interaction between them and the committee members.

When the SMC policy failed to produce results, several incremental changes were made in the policy during the period between 1994 and 2001. According to a PMIU sponsored study (PMIU, 2009) in 2000, SMCs were reconstituted once more and renamed School Councils (SCs). The key change was in the composition of members, with the total requirement for membership again raised to 11, and consisting of teachers, students, two retired government servants and 'lamberdar' (the lowest person in the revenue administration hierarchy). The reconstitution only added to the confusion in education sector, community participation with some SCs continuing to function on the old lines, while others implemented the new rules.

Public policy making is different from policy emulation or borrowing. It is a complex, dynamic, constantly evolving interactive and adaptive process which is driven by the stakeholders. Stakeholders are engaged in a goal-directed decision-making process and iterations are performed in the process until the outcome is produced. The final outcome can be a compromise between the targeted results and the imposed constraints. Civil servants in School Education Department/PMIU know the theory of good policy design, but fail to put it into practice. They usually formulate policy without proper participation of stakeholders and give ad hoc solutions to problems. Notwithstanding continued setbacks in compliance of the policy for thirteen years, PMIU once again ignored the multifarious dimensions of the policy process while revising the policy in 2007, and notified it for implementation. Being conditional under the first phase of Punjab Education sector Reform Programme (PESRP), it was developed with the assistance of the World Bank, Department for International Development (DFID) and Canadian International Development Agency (CIDA). This policy mandated all masjid, maktab, primary and middle government schools to constitute a 7 to 15 member council comprising parents, teachers and other community members. The council members were envisaged to ensure a teachers' presence in school and to increase enrollment through the motivation of parents, conducting co-curricular activities, taking measures to safeguard teachers' and students' rights, providing support in the distribution of free textbooks and stipends in the school and taking measures to protect school buildings.

During the setting-up period, PMIU contracted Rural Support Programs (RSPs) to design and conduct a School Council Capacity Building Program to assist in community 
mobilisation and constitution and training of school councils. Each council was provided a three-day face-to-face training for its role. But a Third Party Validation (TPV) survey conducted by AF Ferguson at the end of PESRP Phase-I, found Cambridge (2014);

(a) Lack of interest and low literacy level of school council members, leading to lack of retention of messages conveyed during the training.

(b) Overall lack of awareness on the part of ordinary members.

(c) A tendency of the head teacher to dominate the affairs of the council.

(d) Non-compliance with the true spirit of the School Council Policy 2007.

Our survey indicates that these findings hold good even today. The third party validation (TPV) report asked for revision of School Council Policy in order to reconstitute and revitalise school councils and bring in a fresher and wider membership. It may be noted that TPV was to ascertain only the compliance with the policy and not the extent to which the policy objectives were achieved. Various studies show that the policy failed to bring the community closer to the school and no improvement in quantity or quality could be attributed to the councils. Channa (2011) examined the early impact of SCs as an important education reform to highlight that the outcome of decentralization depends on context, design and implementation. She found: In its current form, my results indicate that Pakistan's SBM reform is not producing the desired effect. Earlier, in 2010, Habib (2010) while stressing the need for a serious analysis, said:

"The lack of people's participation in the School Councils warrants a serious analysis of the factors behind and also how to create such conditions which encourage and inspire people to come forward and contribute. Their disinterest cannot be attributed to their lack of education or backwardness; it is an outcome of their frustration of the way the state machinery functions and the negligible socio-economic gains it yields for their children and the householders."

Constant failure of the policy highlighted by several studies and recommendations for serious analyses should have shown the way to the architects of community participation policy to understand what constituted a community in our social, cultural and political context and should have dug out which elements of the communities were the destructors from within. There was a need to realize that community mobilization was a serious business that required a painstaking process. Social change could not be brought about just by issuing notifications and producing policy documents. But instead of finding out the causes of its failure, School Council Policy was once again revised by PMIU with the help of its development partners and notified for implementation in March, 2013. Such revision was required under the third party validation report and also as a Disbursement Linked Indicator (DLI) of the development programme. The revised policy increased the number of members from 7-15 to 9-17 and allowed school council membership to the extended family relations of children in the school, and local individuals possessing 
some capacity to influence the local community for good. At the same time, a capacity building program named School Council Mobilization Program was developed and launched. Both initiatives were incorporated into PESRP-II as a Disbursement Linked Indicator (World Bank, 2012, p. 32).

The revised School Councils Policy 2013 was piloted in 50\% of schools (total 2864) of districts Attock, Chiniot, Jhelum, Lodhran and Sargodha with a plan to scale up its implementation in 10 more districts, and thereafter to all 36 districts of Punjab after its review. The revision of the policy was carried out in a very short time as the school councils were to be reconstituted prior to the making of capacity building programme operationalSchool Council Mobilization Programme (SCMP). The administrations of the pilot districts and schools report that they were not consulted during the processes of revising School Council policy or developing SCMP. Interviews with Executive District Officers (EDOs) -Education, District Education Officers (DEOs)-Elementary, Assistant Education Officers (AEOs) and Head-teachers indicated that 70\% of these administrators were not thoroughly familiar with the procedure to be followed for the reconstitution of school councils. One EDO narrated that they were called for a meeting held at Lahore on 29 March, 2013 and were shown slides of the revised policy. Then they were asked to reconstitute school councils in their respective districts and forward a compliance report to this regard latest by 5 April 2013. It was Friday (29 March, 2013) and on next Monday (1 April, 2013), the EDO called a meeting of DEOs, AEOs and selected head teachers of his district. Those who attended the meeting were shown the same slides and the remaining were communicated policy by telephone. This reflects the level of importance given to the participation of stakeholders in the policy making process. Surprisingly, the AEOs who had a pivotal role in constitution, reconstitution and mobilization of the councils, were not provided booklets. They had managed photocopies of policy document through their own efforts. Leaving the key implementers ill-equipped was something that has been happening all along in the case of School Council Policies. Earlier, this lack of badly needed administrative, logistical and technical support to AEOs was pointed out (Habib, 2010).

Similarly, schools where the policy was to be complied with and implemented were not issued School Council Policy booklet. Some of them had managed photocopies from their respective AEOs or district offices. As regards compliance with School Council policy 2013 or its outcome, surveys indicates that revision of 2007 policy was an urgent requirement for bureaucracy due to Disbursement Linked Indicator (DLI) factor and thus new School Council Policy 2013 was issued. But as regards its compliance, all schools had conducted a paper exercise just to meet the deadline of 5 April 2013. The policy failed to find capable, active and dedicated members of School councils. $98 \%$ of the parents/community members serving on school councils did not know about their responsibilities and powers. Maximum of them were of the view that the primary purpose of the council was to arrange financial resources for schools constructed in their areas.

Field work shows head teachers of the rural area schools to be quite critical of the School Council policy. In their view, an ordinary parent from village does not possess the capacity to take on the tasks assigned to school councils. To them, the policy was an eyewash: no body participated in school matters; required signatures were obtained by sending documents / registers to members at their residences and sometimes teach- 
ers signed against their names. While criticising decision regarding utilization of school council's fund, they complained that members neither understood nor participated in any development programme but it was imperative to manage/get their signatures. Sometimes members hesitated to sign certain documents due to their own apprehensions. As regards compliance of the policy for the reconstitution of the councils, all head-teachers told that most people were reluctant to become members of the council even after repeated requests by head-teachers/teachers, so holding of any general body meeting or election for school council membership was never carried out. In response to a question about capacity building programmes, $90 \%$ heads of schools opined that the exercise carried out in the recent past was futile and wastage of time and resources, $10 \%$ of them appreciated the methodology and efforts of Rural Support Programme which benefitted head-teachers and literate members of the School Councils but nobody spoke in favour of SCMP. Commenting on the methodology of SCMP under which texts were sent to different members to enhance their knowledge about the functioning of school councils, they told that rural parents were hardly able to attend calls on their cell phones, and expecting them to read and comprehend any text would be naive. One head-teacher raised a pertinent question that if nothing was done in developing the capacity of 95 concerned AEOs, what could be done for 48,688 members of 2864 school councils. He remarked that all programmes were based on personal motivations / interests of the decision makers.

The compilation of this researcher's survey coincided with the publication of the third party review report of Cambridge Education. PMIU engaged services of Cambridge Education for undertaking an independent third party review of Implementation of Revised School Council Policy (2013) and School Council Mobilization Programme (SCMP). The review report mostly confirms survey findings related to non-participation of stakeholders in the policy formulation process, non-compliance of the policy in the constitution of councils, lack of interest/awareness about the roles and responsibilities among the community members.

SBM reforms need not be standard or uniform throughout the country, province, region or even district. Arrangements and their impacts vary from context to context. However, all such reforms are based on two key dimensions:

(a) Degree of autonomy in decision making being devolved.

(b) People to whom the decision-making authority is being devolved.

Since there are so many possible combinations of these two dimensions, almost every SBM reform is unique. Each arrangement is shaped by the objectives of the reformers and by the broader national policy and social context in which it is created. However, in case of Punjab, all schools are required to follow the same model. Policymakers and their development partners failed to realize that participation of the community in development efforts depends on the capacities of the community members. Also, there is an obvious difference between the capacities and awareness of the urban and rural communities and even among populations of various regions/districts of Punjab. One may be able to find the required number of dedicated and capable members of a school council from the neighborhood of an urban area school, but may not succeed in finding the 
same number of dedicated and capable people in one complete union council of rural area having 5-6 schools. Action Aid's sponsored study (Habib, 2010) about the participation of local people in education says, "Community members do not pay attention at all. They do not like to come as they do not have time." As a matter of fact, one single participation policy cannot be standardized or generalized for different regions or parts of any country or province due to the different configurations of communities. Different development histories of various regions, different social relationships and cultural traditions necessitate tempering various participatory approaches for their adaptation to local conditions. Khan (2007), in his study of school councils' role, suggests that "when change is built on tradition and takes local customs into account, communities are more likely to be receptive to change." Any policy designed for community participation, but without accounting for the heterogeneities of the communities is destined to fail at the implementation phase.

In the case of Pakistan in general and Punjab in particular, bureaucratic system tries to coordinate till the last point in the chain - the school and the teacher but does not reach to the wider community. Sometimes in order to bridge the gap between the community and the school, local institutions such as the School Councils or School Management Committees have been set up. In practice, however, these have been utilized by the governments to execute and implement their schemes and there is no participation of communities in decision making process of the schools. Ownership cannot be built and enhanced without involving stakeholders in decision making process. Thus, without ownership, compliance or implementation of any policy remains a distant dream. Ground survey shows that no ownership for school council policy exists at any level of its implementation from the office of DPI down to the teachers/parents/community. Furthermore, School council policy in Punjab is a classic example of tokenism where a marginal change is presented all wrapped up in new packages simulating new policies. Around thirteen notifications and five policy booklets have been issued since 1994 but without any substantial change. The incremental changes made from time to time mainly pertain to number of SC members and pendulum swings of its headship between head-teacher and parent/community member. NGO run schools are relatively better off due to the innate pattern of their work which demands mobilizing, organizing and capacity-building of communities. But they too fail to mobilize communities and build leadership from within the community as they are forced by the prevalent trend into provision of finance and hardware and become victims of adhocism.

\section{Conclusion}

In Punjab, making or revising school council policy has traditionally been seen as core responsibility or prerogative of the School Education Department / PMIU. Several attempts to design and revise the policy have been made since 1994 but no version of the policy could bring community closer to school. Concerns are expressed about the weaknesses underlying the policy making process and the way policies are being made. But development of high quality policy depends on the culture that consistently challenges policy 
making process. At PMIU, the process is closed and is not subject to external scrutiny, thus unable to render a quality policy advice. At the same time, there exists no mechanism or expertise to ascertain the quality of the policy process. The obvious results are poor internal quality control, and limited systematic learning and improvement. Secondly, policymakers work under different pressures and instead of overseeing long-term results, they just manage crisis situations. These pressures need to be recognized and policymakers need to be helped to sail through them. School Education Department/PMIU has to change its policy role in order to overcome these challenges. Instead of following past practices or imported models, they need to develop their capabilities to guide and facilitate district educational administrations, schools and communities on setting frameworks suiting to their environments and capacities rather than focusing on the delivery of outcomes by themselves.

Solution to a problem is implicit in its identification. It is incumbent on one to collect input from all stakeholders for analysis and resolution of the problem. Basing on the data collected from the stockholders the researcher suggests that the school education department needs to devolve planning and management to district/tehsil educational bureaucracies, union councils, schools and communities. They should be allowed to decide the composition of their councils and spell out roles and responsibilities. When they have their lowest tier of governance - union councils - in place, their elected representatives may participate in determining practices best suited to their constituencies. Such plans will have ownership and help generate a better system of accountability. Schools will be responsible to elected members of the union council and members responsible to the community. However, the union councils may be mandated to incorporate in the educational/school management committee 3 to 4 community members who have interest and expertise in education. Structure and establishment should be done in consultation with members of the union council, local educational bureaucracy, head-teachers and teachers. In addition the researcher suggests that instead of relying on foreign evaluators, the evaluation studies be assigned to educationists / experts from Pakistan/Punjab. Such studies should be restricted to particular regions level and may not be generalized for the entire province. 


\section{References}

Cambridge, E. (2014). Review of Implementation of School Council Policy 2013: Implementation of School Council Mobilisation Programme (Final report) TA 34. Beinformed, Netherland.

Channa, A. (2011). Can school decentralization improve learning?: Autonomy, participation and student achievement in rural Pakistan. Working Paper Series, No.11-115, London.

De Grauwe, A. (2005). School-based management (SBM): Does it improve quality. paper commissioned for the EFA Global Monitoring Report 2005, the quality imperative, UNESCO.

Geurts, T. (2014). Public policy making: The 21st century perspective. Beinformed, Netherland.

Government of Pakistan. (1959). Report of the Commission on National Education: JanuaryAugust 1959. Karachi: Ministry of Education. (Tech. Rep.).

Government of Pakistan. (1972). New Education Policy 1972-80. Islamabad: Ministry of Education. (Tech. Rep.).

Government of Pakistan. (1992). Educational Policy 1992. Islamabad: Ministry of Education. (Tech. Rep.).

Government of Pakistan. (1998). National Education Policy 1998-2010. Islamabad: Ministry of Education. (Tech. Rep.).

Government of the Punjab. (1994). Education Department Notification No. SO(SAP)22/94 dated 26 September, 1994, regarding Constitution of Committees to implement SAPP. (Tech. Rep.).

Habib, N. (2010). Situation analysis of school councils in five districts of Punjab. Lahore: Khoj - Society for people's education in partnership with Actionaid.

Khan, F. (2007). School management councils: A lever for mobilizing social capital in rural Punjab, Pakistan? Prospects, 37(1), 57-79.

Shaeffer, S. (1992). Collaborating for educational change: The role of parents and the community in school improvement. International Journal of Educational Development, 12(4), 277-295.

Weiler, H. (1990). Decentralisation in educational governance: An exercise in contradiction. 